\title{
Causes of the European Union's Decreasing Position in the Global Economy in 2000-2016
}

\begin{abstract}
The subject of the paper is an analysis of the economic results of the main factors affecting GDP growth in the European Union in 2000-2016. The aim is to evaluate the global position of the EU as well as to identify the main factors affecting growth of the EU's economic potential and effectiveness. The analysis also includes the long-term development gap in the EU-15/EU-28 versus the U.S.A. Quantitative and qualitative criteria were used in the assessment. Quantitative criteria include: growth rates of GDP, investments and exports, the EU's share in global GDP, and global exports of goods and services. The qualitative criteria are: labour productivity and total factor productivity TFP. The results of the study are as follows: 1) evaluation of the EU position in the global economy (quantitative indicators) show a decline in the EU's share in global GDP, and trade and FDI were not greater than in the U.S.A.; 2) pertaining to the qualitative criteria the United States ranks better; 3 ) factors contributing the most to the weakening of the global economic position of the EU are: lower investment in the ICT sector compared to the U.S., differentiation of EU members in terms of their ability to grow, socio-economic divergence and a crisis in the eurozone.
\end{abstract}

Key words: global economic powers, growth factors, growth barriers, EU global position

JEL Classification: F50, O47, P16

\section{Introduction}

The economic position of a country, or of a group of countries functioning as a common market, is dependent upon a number of factors impacting the development process both in quantitative terms as well as in terms of effectiveness. Conditions for business development are created by domestic and foreign markets. Countries with large domestic markets have greater opportunities for growth and can gain from economies of scale. In contrast, countries with smaller domestic economic potential and markets are more prone to join various free trade areas, allowing for more extensive internationalization of economic activity and strengthening of international economic positions for businesses. Economic expansion leads to an increase in international and global economic links. As a result, international markets play an ever-increasing role as a development regulating mechanism both globally and for countries that are strongly connected to the world economy.

The rise and development of an international economic space, and most especially the globalization of economic links and flows as brought about by one of the first global empires - the United Kingdom - led to the creation of an economic system beyond national borders. This system required new rules to regulate how it functioned and how it was controlled. Thus was raised the question of how to manage a world economy. The answer to that cannot be given without assessing the structure of the economic power of certain nation-states, since they are the participants in the world market who can influence it with

${ }^{1}$ prof. dr hab., Chair of World Economy and European Integration, Faculty of Economics, post address: Plac Marii Curie-Skłodowskiej 5, 20-031 Lublin, e-mail: mucha@hektor.umcs.lublin.pl 
the strength of their large domestic markets. They affect global development opportunities and impose conditions for conducting international economic activity upon economically weaker partners. The vast advantage of a country or a group of countries, as measured by their economic potential and effectiveness, allows them to play a dominant role in international economic relations and to achieve larger gains. This is due to their ability to control market conditions and is a consequence of policies aimed at taking-over profits from international merchandise and service trade as well as capital flows.

A system of economic power based on the leadership of a single economic center is known as a monocentric system. The main examples of this are the two stages of world economic development known as Pax Britannica (19th century until the beginning of World War I) and Pax Americana (1945 - 1973). During the period between World War I and World War II, the system of powers was polycentric. After the economic domination of the United States began to decline after an improvement of the European Economic Community (EEC) and Japan's economic position, the system of powers evolved into an economic triad. After the year 2000, due to an increase in the positions of China, India and Brazil, the polycentric system has widened even more.

The European Economic Community began developing the Single European Market project in earnest in the mid-1980s. It accelerated monetary integration and introduction of the common currency, in particular as a result of the removal of barriers to capital flows (1990). Maintaining fixed exchange rates and free movement of capital as well as national monetary policies (regardless of any attempts at coordination) became unrealistic. The French plan of economic and monetary union created by president F. Mitterand and J. Delors (then Chairman of the Commission of the European Communities) was implemented. Achievement of higher stages of integration in the EEC/EU as well as disintegration of the political and economic system of the Soviet Union raised interest in the EU membership among the rest of the European countries. As a result of subsequent enlargements, the EU now includes two groups of countries - the "old" EU members (EU15) and the new member states (EU13). The European Union as a group of countries limited by the borders of the common market is the second largest economic center of the world, comparable to the United States. However, not all measures and criteria of assessing economic power confirm that. The main problem is derived from the size of the EU's technological gap vis-a-vis the United States. Technological lag contributes to a slowdown in labour productivity and structural changes. It leads to a decline in competitiveness and decreases economic growth rates. If these regressive tendencies persist in the long-term, the economic gap deepens, weakening the position of a country (or a group) in the global system of powers, limiting its chances of assuming a leadership role or of taking control of international markets by affecting prices and shaping global economic policy in ways more favourable for achieving economic objectives. The European Union in its history has experienced periods of dynamic economic growth. However, since the mid-1990s, when the economic gap vis-a-vis the United States began to deepen, it has not regained its ability to stabilize economic growth. Furthermore, research reveals that socio-economic cohesion of the EU is weakening - in particular the crisis of 2008-2009 strengthened the process of economic and social divergence.

The paper relies on an approach that emphasizes the competition between economic superpowers and the shifting balance of world forces. The main research questions are: why is the global economic position of the EU weakening and what are the driving forces affecting shifts in the global economic order. There is a plethora of literature available on 
the subject of the paper to serve as theoretical background for empirical analysis. The variety of research is derived from different ideological traditions and varied schools of economic thought. International and global political economy provides the theoretical framework for contemporary researchers, who explore competition between the winners and losers of global economic exchange and the impact of economic superpowers on creating the conditions for development of international business (Frieden, 2006; Keohane, 1984; Oatley, 2008; Palan, 2000).

The goal of the paper is to evaluate economic results and the global position of the European Union and to identify the main factors affecting the economic power and effectiveness of the EU, as well as its impact on the global economy in the period of 2000-2016. Assessment of the global position of the EU was based on the following measures: GDP growth rate, investment, exports, labour productivity growth rate and its level compared to the U.S., total factor productivity (TFP) growth rate as well as EU's shares in world GDP, exports, imports and foreign direct investment flows.

The EU results are compared with the largest members of the world economy. The U.S. is a benchmark country. Remaining reference countries are: China, Japan and Germany. The data used in the analysis were obtained from the following databases: Eurostat, IMF, World Bank, OECD, UNCTAD and the Conference Board.

\section{Long-term development gap in EU-15/EU-28 versus the U.S. in 1950-2016}

Table 1 includes periodical averages for EU15 economic growth rates and for all EU members (since 1996). GDP growth rates allow for the clear distinction of five sub-periods within 1950-2016, characterized by different rates of EU convergence to the U.S. However, if we only take into consideration the diminishing the economic gap, there are only two subperiods: 1950-1995 and 1996 - 2016.

Since the mid-1990s the EU development gap has been growing. The growth rate declined in 2000-2007 and then increased alongside the financial, economic and debt crisis. Data in Table 1 reveal that high growth dynamics in the EU15 until the 1970s was a result of intensive industrialization and increasing labour productivity based on modern technologies and supported by high investment activity of U.S. corporations in Europe, contributing to the increase in labour productivity and Europe's trade competitiveness. The FDI value increased from 1.7 billion USD in 1950 to 40 billion USD in 1970 (Maddison, 1982, p. 128). In 1972-1995 the rate of closing the EU15 economic gap slowed down, even though labour productivity growth was still higher than in the U.S. The factor limiting GDP growth was low labour input - employment did not grow at all or grew only slightly until the mid-1980s, and the persistence of high unemployment rates was becoming both an economic and social problem. On the other hand, job creation was booming in the U.S. and Japan. In the EU15 industry employment declined from the mid-1970s to the mid-1980s (Hansen, 2003, p. 49-53). Average annual employment growth rate in EU15 for 1961-1991 was $0.4 \%$, in the U.S. it was $1.8 \%$ and $1.0 \%$ in Japan (Hansen, 2003, p. 76). Low employment growth rates in EU15 positively impacted labour productivity growth and competitiveness of trade. 
Table 1. Long-term growth tendencies in the European Union and the United States

\begin{tabular}{|c|c|c|c|}
\hline $\begin{array}{l}1950- \\
1973\end{array}$ & $\begin{array}{l}\text { Closing the } \\
\text { development gap } \\
\text { due to high GDP } \\
\text { and labour } \\
\text { productivity growth } \\
\text { rates. }\end{array}$ & $\begin{array}{l}\text { GDP (average annual growth rates): } \\
\text { UE- } 15 \text { around } 5 \% \text {; the U.S. } 3.7 \% \\
\text { Labour productivity (annual growth } \\
\text { rates): UE- } 15 \text { around } 5 \%-5.3 \% \text {, the } \\
\text { U.S. } 2.5 \% \text {. } \\
\text { Growth of GDP per capita in UE- } 15 \\
\text { from } 45.5 \% \text { of the U.S. level in } 1950 \\
\text { to } 76.8 \% \text { in } 1973 \text {. }\end{array}$ & $\begin{array}{l}\text { Intensive industrialisation } \\
\text { in Europe. }\end{array}$ \\
\hline $\begin{array}{l}1973- \\
1995\end{array}$ & $\begin{array}{l}\text { Deceleration in the } \\
\text { process of closing } \\
\text { the development gap }\end{array}$ & $\begin{array}{l}\text { GDP: EU-15 } 2.0 \% \text {; the U.S. } 2.8 \% \\
\text { Labour productivity: EU-15 } 2.4 \% \text {; } \\
\text { the U.S. } 1.2 \%\end{array}$ & $\begin{array}{l}\text { One main feature of the } \\
\text { Community's economic growth } \\
\text { was decreasing labour input, } \\
\text { employment rate in } 1993 \text { was } \\
58 \% \text {. }\end{array}$ \\
\hline $\begin{array}{l}1996- \\
1999\end{array}$ & $\begin{array}{l}\text { Development gap } \\
\text { deepened - ICT } \\
\text { revolution in the } \\
\text { U.S. }\end{array}$ & $\begin{array}{l}\text { GDP: UE-15 } 2.7 \% \text {; UE-28 } 2.7 \% \text {; } \\
\text { the U.S. } 4.9 \% \\
\text { Labour productivity: UE-15 } 1.3 \% \text {; } \\
\text { UE-28 } 1.5 \% \text {; the U.S. } 2.7 \%\end{array}$ & $\begin{array}{l}\text { Particularly low growth compared } \\
\text { with the U.S. occurred in Italy } \\
\text { and Germany. }\end{array}$ \\
\hline $\begin{array}{l}2000- \\
2007\end{array}$ & $\begin{array}{l}\text { Slower rising of } \\
\text { development gap }\end{array}$ & $\begin{array}{l}\text { GDP: UE-15 2.3\%; UE-28 } 2.6 \% \text {; } \\
\text { the U.S. } 3.0 \% \\
\text { Labour productivity: UE-15 } 1.1 \% \text {; } \\
\text { UE-28 } 1.5 \% \text {; the U.S. } 2.5 \%\end{array}$ & $\begin{array}{l}\text { The crucial impact on stimulating } \\
\text { demand and GDP growth in the } \\
\text { U.S. was monetary policy. }\end{array}$ \\
\hline $\begin{array}{l}2008- \\
2016\end{array}$ & $\begin{array}{l}\text { The development } \\
\text { gap was growing } \\
\text { faster. }\end{array}$ & $\begin{array}{l}\text { GDP: UE- } 150.4 \% \text {; UE- } 280.6 \% \text {; } \\
\text { the U.S. } 1.4 \% \\
\text { Labour productivity: UE- } 150.2 \% \text {; } \\
\text { UE-28 } 0.4 \% \text {; the U.S. } 1.0 \%\end{array}$ & $\begin{array}{l}\text { Higher GDP growth in the U.S. } \\
\text { resulted from: } \\
\text { a) higher growth of labour } \\
\text { productivity and } \\
\text { employment } \\
\text { b) increasing investment and } \\
\text { private consumption. }\end{array}$ \\
\hline
\end{tabular}

Source: author's own calculations based on (Maddison, 1982, p. 44; Ark van, O'Mahony and Timmer, 2008, 25-44; The Conference Board, 2017a).

A new wave of technological progress based on IC technologies originating in the U.S. resulted in revolutionary structural changes both for domestic economies as well as the world economy. This progress accelerated globalization, in particular in the financial services sector. Thus, taking into account the state of development in the U.S. financial market, technical progress reinforced U.S. global impact. Development of modern business services also contributed to the increase in labour productivity in the U.S. For the first time in decades, in 1996-1999 average annual labour productivity growth rate in the U.S. was higher than in the EU. Due to the weaker utilisation of ICT technologies in the EU as an economic development driving force, the United States increased their advantage over the EU in rivalry for leadership in the world economy. Even though, in 2000-2007 the span of GDP growth rates between the EU and the U.S. declined and the positive tendencies steadied in 2006-2007, the financial crisis reversed this trend. In 2008 - 2016 the indicators of GDP growth, labour productivity, investment and consumption in the EU were significantly lower than in the U.S. and the development gap has been deepening during this time. 


\section{Factors affecting the economic position of the European Union in the global economy in 2000-2016}

Since the beginning of the new millennium, development of the world economy as well as of its main members has been intensified by the following factors: 1) development of merchandise and services within the ICT sector, 2) globalization process, 3) spreading internationalization of production and increasing share of emerging economies in international division of labour, 4) increasing control over international trade by international corporations, 5) sectoral and spatial structural changes, 6) progression of the polycentrization of the system of powers in the world economy revealing ever increasing divergence in economic objectives of the main economic powers on the global market. The concept of creating multilateral rules for the world economy has been losing relevance. This became particularly clear in international trade policy, since from 2001 the U.S. has changed its strategy of trade liberalization. The European Union continues to engage in supporting the development of the global trading system while the United States prefers to include single countries or groups in free trade areas they create. In this way the U.S. link their market to the markets of developing countries which constitute the majority of World Trade Organization members and thus can affect results of trade negotiations (MuchaLeszko, 2014, p. 150, 153).

Among the internal factors of crucial impact on the EU position, the most important ones were: introduction of the common currency and territorial enlargement of 13 new members, out of which the historical breakthrough was accession of the group of countries formerly linked both politically and economically to the Soviet Union. Monetary union in Europe is the greatest change to the international monetary system since the breakdown of the monetary system based on the U.S. dollar and gold, which was established during the United Nations conference in Bretton Woods in 1944. The euro achieved a position as the second international currency. However, the advantage of the U.S. dollar as an international currency remains large, and increased markedly after the 2008-2009 crisis due to the declining confidence in the euro and an increase in the share of alternative currencies in trans-border transactions (Mucha-Leszko, 2014, p. 151-160). The euro has not assumed the position of a global currency - that is still primarily a role played by the dollar. The greatest use of the euro pertains to international trade transactions, which are directly connected to the EU's high market share of global trade turnover. The following data prove the dollar's advantage over the euro in various functions fulfilled by international currencies (Twarowska, 2017, p. 273, 276, 278, 281): 1) share of dollar and euro in trade transactions in 2014 was respectively $51.4 \%$ and $30.5 \%$ (in 2012 it was $47.6 \%$ and $33 \%$ ), 2) share in international loans in $2015-57.7 \%$ and $21.9 \%$ (an increase in the share of dollar and a decrease in the share of euro compared with previous years), 3) share in international deposits in $2015-56.5 \%$ and $24.8 \%$ (an increase in the share of dollar and a decrease in the share of euro), 4) share in foreign exchange reserves in 2016-63.3\% and $20.3 \%, 5$ ) the use of dollar and euro as anchor currencies - 42 countries in the case of U.S. dollar and 25 countries for euro. Expectations for the position of the euro in the global economy were higher than has so far resulted, and according to the data, crisis in the eurozone resulted in the further strengthening of the dollar - it increased confidence in the dollar and decreased confidence in the euro. 
From the point of view of the EU's global economic position, the territorial enlargement occurring gradually since 2004 has been of great importance. The greatest impact on the increase in the EU's share in world merchandise and service trade, capital flows and GDP was due to the accession of 10 Central and Eastern European countries. These new members created opportunities for the development of businesses from EU15 in terms of investment and for themselves - chances for increase in the inflow of foreign direct investment and an easier access to the large market allowing for the achievement of economies of scale. In 2016 EU28 GDP at current prices was 13791 billion euro and the EU13 share of that was 1193 billion euro which was 8.5\% (Eurostat, 2017). Economic potential of the new member states measured by the value of their GDP is relatively low since in 2016 it was higher than the GDP of Spain by only 87 billion euro (Eurostat, 2017). However, development potential of the new members is high due to production capabilities stemming from labour force resources and opportunities of demand creation. The population in EU28 in 2016 surpassed 511 million, and the population of EU13 surpassed 104 million. EU13 population amounts to $20.4 \%$ of total EU population (Eurostat, 2017). Low labour productivity is an important economic growth barrier in the new EU members. In 2016, compared to EU28 average it was varied strongly in EU13 - ranging from 80.5\% in Slovenia, $77.1 \%$ in Slovakia, $76.9 \%$ in Cyprus, $75 \%$ in Malta and $74.2 \%$ in the Czech Republic. The lowest levels of labour productivity occurred in Bulgaria (45.4\%), Latvia (56\%), Romania (56.4\%) and Poland (60.1\%). The remaining 4 countries (Lithuania, Croatia, Estonia and Hungary) had labour productivity of $62.4 \%$ to $63.5 \%$ of the EU28 average (Eurostat, 2017).

The economic crisis of 2008-2009 resulted in an increase in economic divergence of the EU countries, taking into account their GDP per capita, consumption per capita, differentiation of wages and incomes and many other economic measures. Authors of various research focus on the effects of the development process and factors accelerating and decelerating economic growth affecting economic convergence and divergence within the EU. H. Kohl (2015, p. 285-311) used a composite summary index of economic and social cohesion comprised of 35 indicators, revealing a special standard deviation from the EU average. The indexes were calculated for two periods: 2007-2008 and 2012-2013. The results divide EU members into three groups: I) North-Eastern (9), II) Southern plus Ireland (6), III) Central and Eastern European (11). Most in Group I maintained advantages over the EU average in terms of raising economic and social standards. In addition, Germany clearly improved in 2009 - 2013. The only country from the group that, according to the summary index, has experienced divergence was the United Kingdom. Divergence occurred in all countries in Group II. The situation was varied in the case of Group III - it was the best in Slovenia, the Czech Republic and Lithuania and the worst in Romania. Research revealed the impact of the crisis on deepening socio-economic divergence in the Southern EU countries and intensification of adjustment processes in some of the Central and Eastern European countries (Table 2).

Analysis of the impact on economic growth for demand and supply factors can be used to reveal divergence among EU countries in terms of their capability for economic growth, which can weaken the process of convergence. Prior to the 2008-2009 crisis, structural problems of EU economies and economic growth slowdown were the result of high employment growth and low labour productivity growth rates, so supply-side factors. A major factor affecting the situation was modest use of ICT technologies in the developing service sector. However, since the crisis, analysis has focused on the demand-side factors of 
economic growth. Consequences of the crisis varied among countries in terms of GDP losses and labour productivity. The main factors of labour productivity growth stemmed from capital input and in particular the value of capital inputs connected to the use of ICT technologies as well as capital invested outside the ICT technology sector. The driving force of technological progress was connected with the investment in ICT technologies and concentrated in EU15 countries and to a lesser extent in EU12.

Table 2. Summary index of socio-economic convergence and divergence in the EU members in 2007/2008 and $2012 / 2013$

\begin{tabular}{lrr|lrr|lrr}
\hline Group I & $2007 / 8$ & $2012 / 13$ & Group II & $2007 / 8$ & $2012 / 13$ & Group III & $2007 / 8$ & $2012 / 13$ \\
\hline Denmark & 23.2 & 20.7 & Ireland & 5.1 & 0.3 & Slovenia & 11.5 & 10.7 \\
Sweden & 17.2 & 18.8 & Italy & 1.1 & -5.0 & Czechia & -2.5 & -3.3 \\
Belgium & 18.0 & 16.8 & Cyprus & 0.7 & -6.9 & Lithuania & -11.1 & -4.3 \\
Netherlands & 16.6 & 14.8 & Portugal & -8.6 & -12.0 & Estonia & -4.6 & -6.2 \\
Finland & 14.3 & 14.3 & Spain & -6.7 & -13.3 & Slovakia & -6.6 & -6.3 \\
France & 13.6 & 14.2 & Greece & -7.0 & -15.7 & Hungary & -8.3 & -7.9 \\
Austria & 14.3 & 14.0 & & & & Poland & -7.9 & -8.0 \\
Germany & 4.8 & 9.7 & & & & Latvia & -9.4 & -8.9 \\
UK & 3.0 & -0.9 & & & Croatia & -9.0 & -10.2 \\
& & & & & & Bulgaria & -10.8 & -11.4
\end{tabular}

Summary composite index of convergence/divergence is calculated including 35 sub-indexes revealing the balanced special standard deviation from the EU average.

Source: (Kohl, 2015, p. 304).

M. O'Mahony, B.Van Ark (2003) and B. van Ark, M. O'Mahony and M. P. Timmer (2008, p. 25-44) conducted empirical analysis confirming a significant impact of ICT technologies on labour productivity growth in the U.S., and on the EU gap since investment in ICT in the EU was nowhere near U.S. levels. Research on the influence of ICT on economic growth was enriched markedly. Although the results differ depending upon the research method and analyzed groups of countries, they are mostly positive (Farhadi, Ismail, Fooladi, 2012). Authors widen the scope of analyzed factors affecting labour productivity focusing on total factor productivity (TFP), which declined in 2008-2016 in the EU by $0.58 \%$ per annum and in the U.S. only by $0.04 \%$. Detailed data is presented in Table 3.

Table 3. Growth of Total Factor Productivity (TFP) in 2008-2016

\begin{tabular}{l|cccccccccc}
\hline \multicolumn{1}{c|}{ REGION } & 2008 & 2009 & 2010 & 2011 & 2012 & 2013 & 2014 & 2015 & 2016 & $2008-2016$ \\
\hline United States & -1.2 & -0.3 & 1.6 & -0.4 & 0.1 & -0.2 & 0.1 & 0.2 & -0.3 & -0.04 \\
EU-28 & -1.8 & -3.9 & 1.0 & 0.2 & -1.1 & -0.4 & 0.1 & 0.3 & 0.3 & -0.58 \\
\hline
\end{tabular}

Source: author's own calculations based on (The Conference Board, 2017c)

Data show that a decline in TFP was strongly correlated with the fluctuations in the economic cycle. The second wave of recession in 2012-2013 was strong in the EU, and the U.S. experienced just a slowdown in GDP growth which was reflected in TFP changes. 
Since 2014 there have been symptoms of TFP re-launch in the European Union. The problem of TFP growth can be put into a question on factors determining its growth in the long-run. European Investment Bank analysts name the following (European Investment Bank, 2011; European Commission, 2017): 1) educational attainments, 2) lifelong learning and ICT skills, 3) ageing, 4) product market reforms (particularly in the services sector) and reforms of employment protection legislation, 5) public and private R\&D (coupled with liberalizing elements of patent system), 6) ICT and broadband investment, 7) competitiveness and trade openness.

Authors of the quoted European Commission report confirmed in their research that quality of education, business investment in intangible capital, public R\&D expenditure, trade openness and labour market policy positively affect TFP growth whereas ageing of the population decreases TFP dynamics (European Commission, 2017). B. van Ark et al. (2013, p. 7) in their analysis on Europe's growth slowdown in the first decade of the new century, indicate that a decline in total factor productivity might have been a signal of a growing rigidness of markets - labour, merchandise and capital - and as a result - transfer of resources into businesses with lower labour productivity. This hypothesis, however, has not been confirmed.

Analysis of EU's demand-drawn growth potential was carried out by B. van Ark et al. by assessing the capability to create demand within three market segments (Ark van et al., 2013, p. 7): products, commercial services and non-commercial services, taking into account the origin of the demand - domestic or external market. The research revealed a predominance of employment in production segments of the economy that are based on domestic demand for final products. Only $22-23 \%$ of EU employment was in production connected to external demand (including other EU countries). Countries varied in terms of dependence on foreign demand, which is very important for countries like: Germany (23-27\% of employment depends on external demand), Austria (19-26\%) or Poland $(20-28 \%)$. More stagnant in terms of the role of external demand in the first decade of the 21st century were the following: Spain, Italy, France and the United Kingdom. External demand is much more important for commercial services development and is a growing trend. Interesting results show the impact of employment connected with various sources of demand on labour productivity growth. Pro-growth economic potential increases from involvement in production for the global value chain. Processes of integrating within global production networks create opportunities for economic growth through acceleration of technology flows and growing innovativeness, but they also divide EU members into various groups. Those whose economies are more dependent upon domestic markets can be left outside the centers of intensive economic growth that have a dominant position in the EU.

Based on the analysis of supply-side and demand-side factors of economic growth in the EU, B. van Ark et al. distinguished 4 groups of countries using the following criteria (Ark van et al., 2013, p. 15-18): 1) the potential to create sustainable (total factor) productivity growth, 2) the demographic characteristics of countries, 3) the capabilities to invest in tangible and intangible assets, 4) intra-European and global interaction through trade and offshoring. The first group includes Germany, Austria and most of the Central and Eastern European countries integrated within production networks. The second group are the inward-looking countries - the Mediterranean countries. The third group encompasses small economies: Baltic, Nordic, Benelux and Ireland are described as global niche players. The fourth type of economy did not fit any of the above groups - the United 
Kingdom was considered the most deindustrialized economy of the world with a predominant service sector.

To sum up, one can conclude that globalization leads to an increase in worldwide interdependence of businesses and increased dependence of domestic markets on external demand. Development of regional and global value chains leads to the transformation of global economic space and creation of new centers, intensifying technological progress and economic growth. However, development of intra-regional connections and benefits from allocation of high mobility resources can be leveraged through the single market. Once this hypothesis is confirmed, the position of the EU in the global economy will not continue to weaken.

\section{EU's economic results and share in the global economy - comparative analysis to global economic superpowers}

First, I evaluate dynamics of economic growth based on periodic average GDP growth rates. In 2000-2007, EU28 economic growth rate was slightly lower than in the U.S. and higher than in Germany by one percent. The largest EU economy contributed to the lowering of the average growth rate since its share in EU28 GDP was 20.3\%. Low growth rate in Japan resulted in its' declining share in global GDP and the high dynamics in China led to significant changes in the global system of economic powers. China reaffirmed its position as a third global economic center. In 2008-2016, the European Union experienced losses in terms of GDP during the 2009 recession $(-4.3 \%)$ which were greater than in the U.S. $(-2.8 \%)$. What's more, there was a second wave of recession in the EU in 2012-2013, and the recovery began in 2014 (Figure 3). During the period of 2000-2016, the declining trend in EU GDP growth rate was much more pronounced than in the U.S. Thus the development gap towards the U.S. deepened (Figures 2 and 3). High growth dynamics persisted in China due to increasing domestic demand. It's important to point out that in 2008-2016 the largest EU economy - Germany - had an above-average EU-28 economic growth rate.

Table 4. Gross domestic product growth, constant prices (average percent change)

\begin{tabular}{l|cccccc}
\hline \multicolumn{1}{c|}{ Years/Country } & World & $\begin{array}{c}\text { European } \\
\text { Union }(28)\end{array}$ & $\begin{array}{c}\text { United } \\
\text { States }\end{array}$ & Japan & Germany & China \\
\hline $2000-2007$ & 4.5 & 2.6 & 2.7 & 1.5 & 1.6 & 10.5 \\
$2008-2016$ & 3.3 & 0.7 & 1.3 & 0.4 & 1.0 & 8.4 \\
$\mathbf{2 0 0 0 - 2 0 1 6}$ & $\mathbf{3 . 8}$ & $\mathbf{1 . 6}$ & $\mathbf{1 . 9}$ & $\mathbf{0 . 9}$ & $\mathbf{1 . 3}$ & $\mathbf{9 . 4}$ \\
\hline
\end{tabular}

Source: author's own calculations based on: (International Monetary Fund, 2017). 


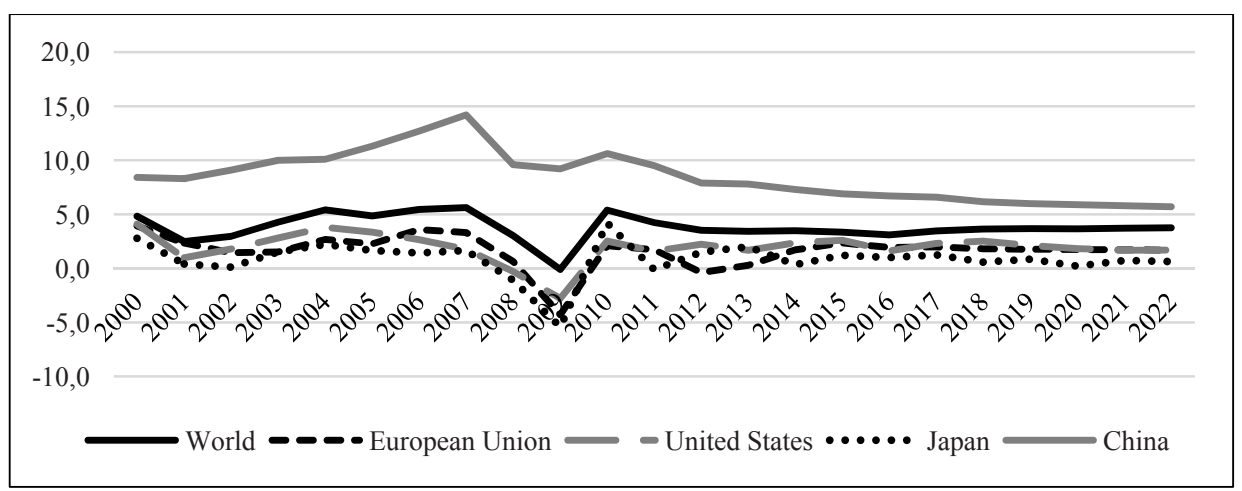

Fig. 1. Gross domestic product growth, constant prices (percent change)

Source: author's own calculations based on: (International Monetary Fund, 2017).

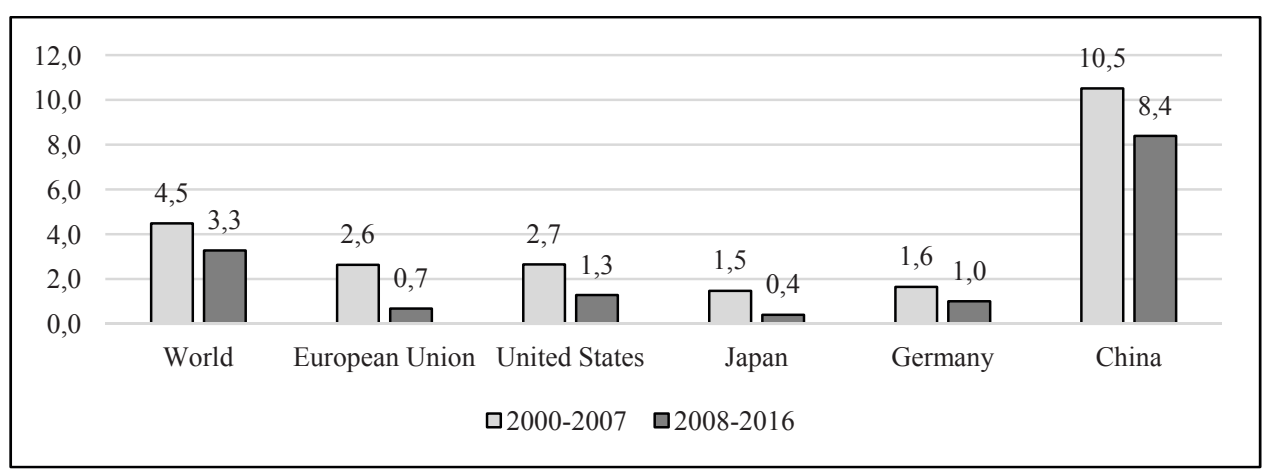

Fig. 2. Gross domestic product growth, constant prices (average percent change)

Source: author's own calculations based on: (International Monetary Fund, 2017).

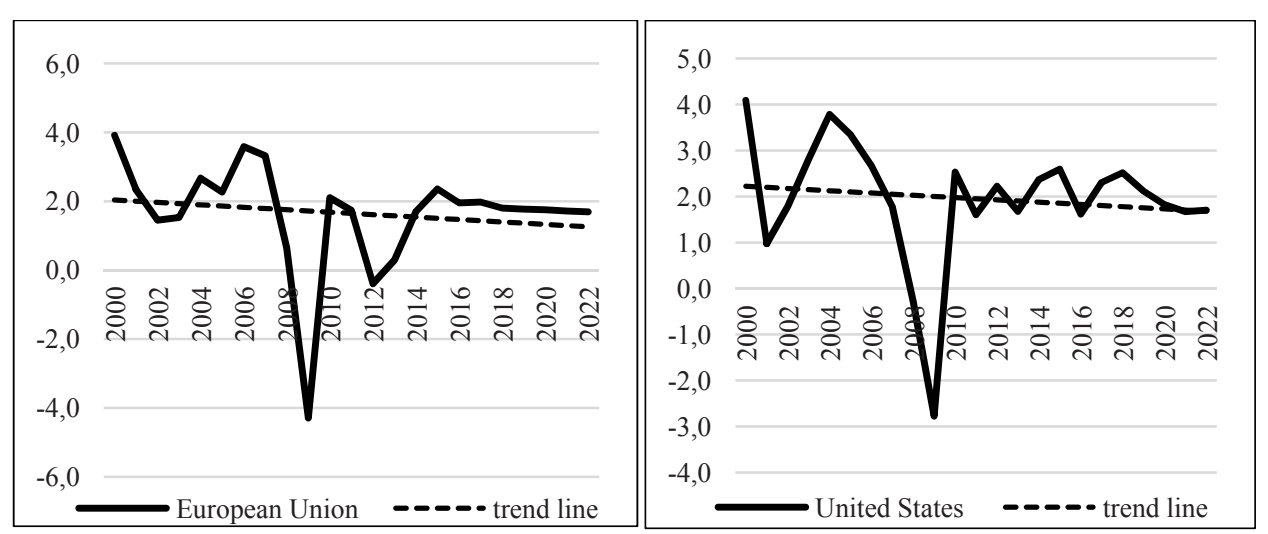

Fig. 3. Gross domestic product growth (percent change) and trend

Source: author's own calculations based on: (International Monetary Fund, 2017). 
In conclusion, diverse GDP growth dynamics in the main economic centers of the world were reflected in the changes of their shares in the global product in 2000-2016. China's share increased by 10.4 p.p., ranking it the top economy of the world. Both the EU's share declined by 6.9 p.p. and the United States' by 5.1 p.p. (Table 5 and Figure 4). Before, the two economic superpowers ranked at the top - with a large margin over China and Japan. They were surpassed by China, which experienced high growth dynamics derived from foreign direct investment, outsourcing, exports and growing labour productivity. IMF forecasts predict that until 2022 China will keep increasing its share in the global product, reaching $20.4 \%$, and the shares of the EU and the U.S. will decline even further, respectively to $15.0 \%$ and $14.1 \%$. Nevertheless, in 2019 China's GDP growth rate is predicted to have declined to $6.0 \%$ and the downward trend is predicted to persist (IMF, 2017). Another wave of technological progress might result in further shuffling in the system of powers. Capital flows and foreign investment contributed the most to the intensification of economic activity in Asia, except in Japan, whose position has been weakened.

Table 5. Gross domestic product based on purchasing-power-parity (PPP) share of world total (in \%)

\begin{tabular}{|c|c|c|c|}
\hline Country & 2000 & 2016 & $2022 *$ \\
\hline European Union (28) & 23.6 & 16.7 & 15.0 \\
\hline United States & 20.6 & 15.5 & 14.1 \\
\hline Germany & 4.9 & 3.3 & 2.9 \\
\hline Japan & 6.8 & 4.4 & 3.7 \\
\hline China & 7.4 & 17.8 & 20.4 \\
\hline
\end{tabular}

*Forecast

Source: (International Monetary Fund, 2017).

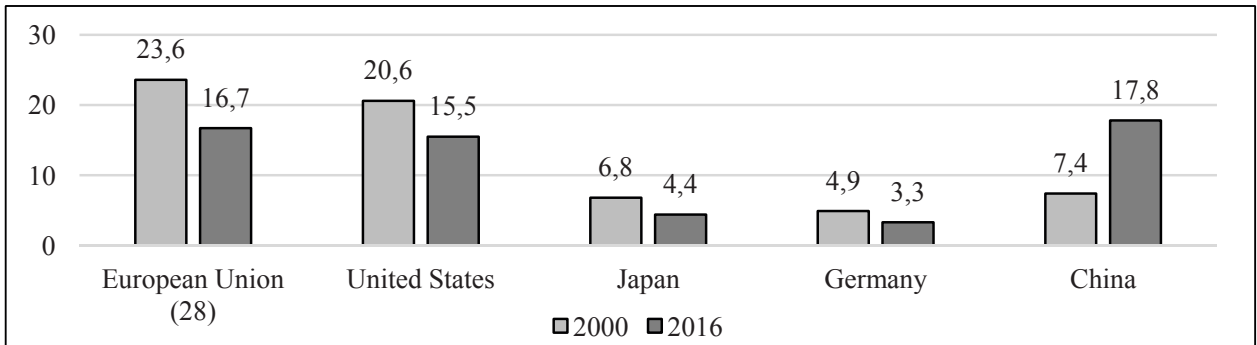

Fig. 4. Gross domestic product based on purchasing-power-parity (PPP) share of world total (in \%)

Source: author's own calculations based on: (International Monetary Fund, 2017).

Differentiation of GDP growth rates in the analyzed global economic superpowers raises a question on the causes of this phenomenon. The main factor leading to long-term economic growth is labour productivity. Rates of labour productivity growth in the developed countries and the EU28 were comparable, with the exception of the U.S., which in both analyzed sub-periods achieved higher labour productivity growth than Japan, Germany and EU28. This was due to the technological advantage the U.S. gained through investment in ICT technologies. Exceptionally high labour productivity growth in China contributed to the closing of the gap towards the developed countries in that respect. 
However, indicators on labour productivity in EU28, Japan, Germany and China in relation to the U.S. level in Table 6 and Figure 7 point to extremely low labour productivity in China. On the other hand, labour productivity in Germany is almost on the U.S. level. The European Union consists of both highly developed and medium developed countries. The average labour productivity in the EU is $3 / 4$ of the U.S. level and in Japan it is only $2 / 3$. Labour productivity can be improved with capital input. EU28 investment declined during 2008-2016 - in Japan, in both analyzed periods, and in Germany, the annual investment growth rate was low.

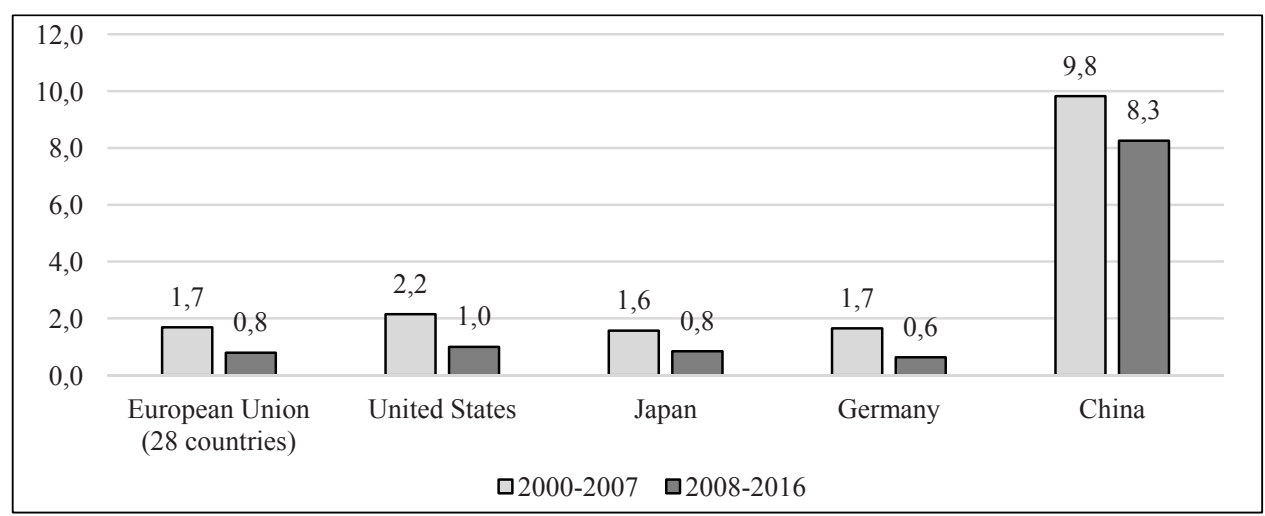

Notice: Labour productivity for China measured as GDP per person employed.

Fig. 5. Labour productivity growth (GDP per hour worked, constant prices, percent change)

Source: author's own calculations based on: (OECD, 2017).

Table 6. Level of labour productivity (GDP per hour worked; USA=100)

\begin{tabular}{l|cccc}
\hline Year & $\begin{array}{c}\text { European Union } \\
(28 \text { countries })\end{array}$ & Germany & Japan & China \\
\hline 2000 & 74.0 & 94.9 & 69.8 & 6.9 \\
2001 & 74.4 & 96.1 & 69.3 & 7.4 \\
2002 & 74.7 & 95.9 & 69.4 & 7.8 \\
2003 & 73.1 & 94.8 & 67.8 & 8.4 \\
2004 & 72.4 & 94.1 & 67.8 & 9.0 \\
2005 & 70.8 & 91.6 & 67.1 & 9.8 \\
2006 & 72.8 & 92.7 & 66.6 & 10.9 \\
2007 & 73.2 & 93.4 & 66.6 & 13.4 \\
2008 & 74.1 & 93.9 & 66.0 & 14.5 \\
2009 & 72.2 & 90.9 & 63.3 & 15.5 \\
2010 & 72.6 & 90.9 & 63.8 & 16.7 \\
2011 & 73.8 & 93.4 & 63.8 & 17.9 \\
2012 & 74.6 & 93.7 & 64.5 & 19.1 \\
2013 & 76.5 & 96.1 & 66.4 & 20.2 \\
2014 & 76.7 & 97.2 & 65.5 & 21.4 \\
2016 & 77.2 & 97.4 & 66.6 & - \\
\hline
\end{tabular}

Notice: Labour productivity for China measured as GDP per person employed.

Source: (OECD. 2017). 


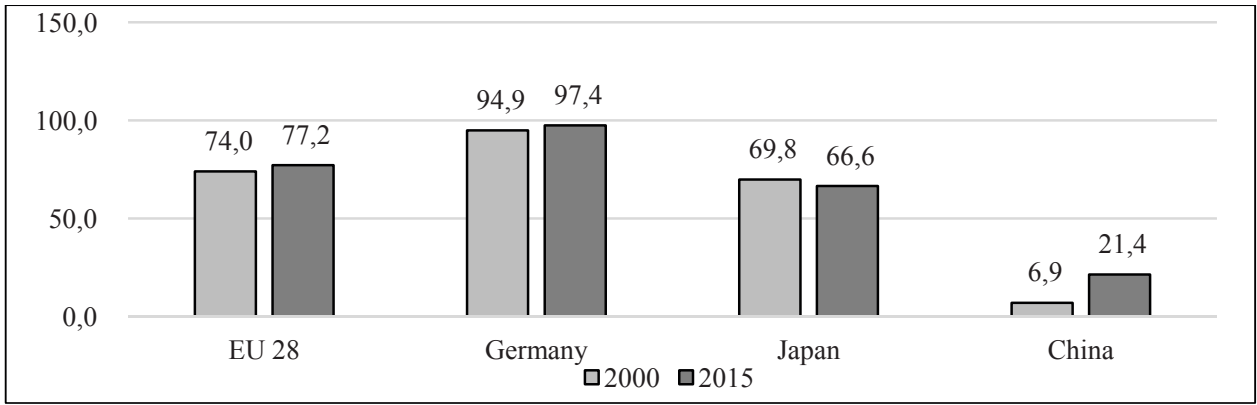

Fig. 6. Level of labour productivity (GDP per hour worked; USA=100)

Source: author's own calculations based on: (OECD. 2017).

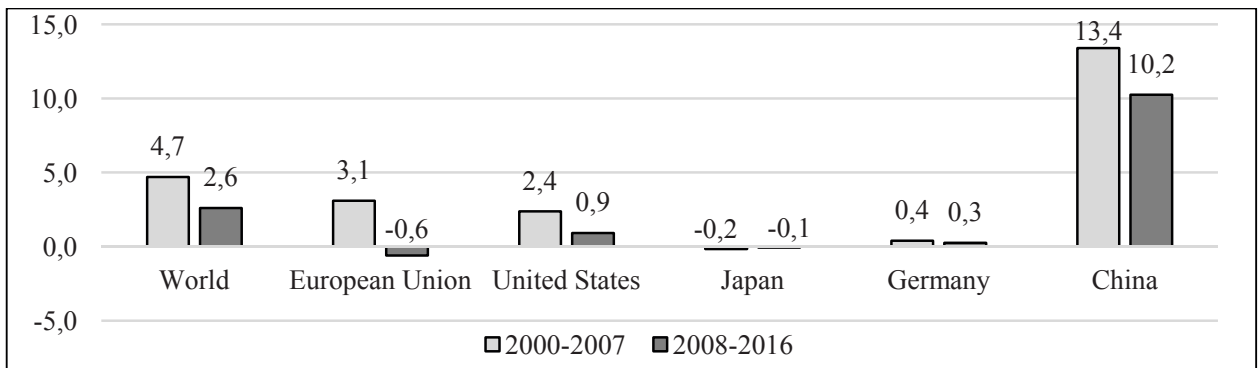

Fig. 7. Average growth rate of gross capital formation (\%)

Source: author's own calculations based on: (World Bank, 2017).

As a result of spreading economic openness and globalization, the input of external demand into economic growth plays a larger role, reflected in the growth of exports. The common EU market creates vast opportunities for growth stemming from intra-EU trade in merchandise and services. Competition on the internal market becomes a leverage in gaining global competitive advantage. It is of particular importance for countries with a development gap, creating opportunity for better adjustment to global competition. The European Union is the largest member of international trade and thus has a strong ability to affect global trade relations, including international trade policy. Maintaining a firm position in trade is a basic precondition for the EU to remain a leader in the global economy in a more general sense. Analysis of exports and imports of goods and services of all main world market participants in 2000-2016, including their shares in global service and merchandise trade, allows for an assessment of the EU's economic position in the polycentric system of powers at current stage of world economy's development.

Export development experienced large fluctuations of turnover. The main factors affecting its dynamics are: technological progress, overall economic growth, transport costs, trade liberalization (including regional trade agreements), foreign direct investment and development of regional as well as global value chains. In 2000-2016 the following factors had the most significant impact on merchandise and services exports: technological progress and economic situation, though non-tariff measures are also worth mentioning. Data in Table 7 allow for a conclusion that weakening of economic growth and recessions resulted in a significant decrease in export growth rate and in 2009 - a very deep decline in 
absolute terms. EU export dynamics in 2000-2007 was higher than in the U.S., because in 2001-2002 - during an economic downturn - the U.S. experienced a steep decrease in its exports. The European Union reached global export levels in 2000-2007 (in terms of average growth rates). However, in 2008-2016, the EU position in world trade diminished, mostly as a result of a deep fall of exports in the recession year of 2009. In particular, a decline in Germany's exports negatively contributed to the EU's exports value in 2009. Countries characterized by larger trade openness were more sensitive to the consequences of declining external demand compared to the United States, which is reflected in Germany's low export growth rate in 2008-2016. During the period of 2000-2016, the average rate of EU exports was comparable to the other analyzed economies. Indicators of their shares in world exports in Table 8 reveal that a decline in the shares of EU28, the U.S. and Japan was mainly the result of an increased share of China. The stable trade position of Germany stands out, as it was the only country that kept its share in world exports in 2016 at the same level as in the year 2000. In terms of services exports, the European Union is a dominant player on the global market with a fairly stable position. A share of over $40 \%$ of the global services trade empowers the EU to create standards and affect prices and competition policy. However, this will soon change with the United Kingdom leaving the EU, as it is the UK who has a large advantage in IT services, business services and above all in financial services. Assessing the EU's trade position, the following conclusions can be formed: 1) export dynamics in both merchandise and services trade is similar to world averages, 2) share in global turnover is lower than in 2000-2008, but in comparison with the U.S. and Japan it can still be considered good, 3) the EU maintains a steady position in services trade, but this might change due to upcoming Brexit.

Table 7. Annual growth rate of exports of goods and services (\%)

\begin{tabular}{|c|c|c|c|c|c|}
\hline Year & World & European Union & United States & Japan & Germany \\
\hline 2000 & 11.92 & 12.90 & 8.57 & 12.74 & 13.83 \\
\hline 2001 & 0.45 & 3.70 & -5.84 & -6.71 & 5.71 \\
\hline 2002 & 2.80 & 2.37 & -1.72 & 7.76 & 4.25 \\
\hline 2003 & 4.34 & 1.73 & 1.76 & 9.52 & 1.90 \\
\hline 2004 & 10.16 & 8.12 & 9.75 & 14.27 & 11.45 \\
\hline 2005 & 6.80 & 5.99 & 6.25 & 7.17 & 6.66 \\
\hline 2006 & 8.57 & 9.44 & 9.04 & 10.31 & 12.29 \\
\hline 2007 & 6.58 & 6.26 & 9.27 & 8.67 & 9.31 \\
\hline 2000-2007 average & 6.45 & 6.32 & 4.63 & 7.97 & 8.17 \\
\hline 2008 & 2.70 & 1.32 & 5.74 & 1.56 & 1.93 \\
\hline 2009 & -10.16 & -11.72 & -8.79 & -23.43 & -14.27 \\
\hline 2010 & 11.59 & 10.67 & 11.89 & 24.91 & 14.53 \\
\hline 2011 & 6.56 & 6.60 & 6.85 & -0.25 & 8.28 \\
\hline 2012 & 2.90 & 2.36 & 3.42 & -0.09 & 2.83 \\
\hline 2013 & 2.99 & 2.21 & 3.48 & 0.76 & 1.85 \\
\hline 2014 & 3.61 & 4.43 & 4.27 & 9.29 & 4.08 \\
\hline 2015 & 3.39 & 6.39 & 0.11 & 3.03 & 5.16 \\
\hline 2016 & 2.69 & 3.11 &.. & .. & 2.62 \\
\hline 2008-2016 average & 2.92 & 2.82 & 3.37 & 1.97 & 3.00 \\
\hline 2000-2016 average & 4.58 & 4.46 & 4.00 & 4.97 & 5.44 \\
\hline
\end{tabular}

Notice: Data for China is not available

Source: author's own calculations based on: (World Bank, 2017). 
Table 8. Shares of trade in goods (percentage of total world)

\begin{tabular}{c|rcrrr}
\hline YEAR & EU28 & United States & Japan & Germany & China \\
\hline 2000 & 38.0 & 12.1 & 7.4 & 8.5 & 3.9 \\
2003 & 41.9 & 11.0 & 5.6 & 9.3 & 5.2 \\
2004 & 40.9 & 8.8 & 6.1 & 9.9 & 6.4 \\
2007 & 38.2 & 8.2 & 5.1 & 9.4 & 8.7 \\
2008 & 36.8 & 8.0 & 4.8 & 9.0 & 8.9 \\
2009 & 36.7 & 8.4 & 4.6 & 8.9 & 9.6 \\
2010 & 33.9 & 8.4 & 5.0 & 7.6 & 10.3 \\
2012 & 31.4 & 8.4 & 4.3 & 7.5 & 11.1 \\
2015 & 34.1 & 10.7 & 3.7 & 8.4 & 11.2 \\
2016 & 33.7 & 9.1 & 4.0 & & 13.1
\end{tabular}

Source: author's own calculations based on: (UNCTAD, 2017).

Table 9. Shares of trade in services (percentage of total world)

\begin{tabular}{c|ccccc}
\hline YEAR & EU28 & United States & Japan & Germany & China \\
\hline 2000 & 43.4 & 19.0 & 4.5 & 5.5 & 2.0 \\
2003 & 48.1 & 15.6 & 4.1 & 6.5 & 2.5 \\
2004 & 48.0 & 14.9 & 4.2 & 6.4 & 2.8 \\
2007 & 47.8 & 13.6 & 3.4 & 5.9 & 3.5 \\
2008 & 47.2 & 13.3 & 3.5 & 6.0 & 3.6 \\
2009 & 46.1 & 14.3 & 3.4 & 5.2 & 3.4 \\
2010 & 44.0 & 14.4 & 3.4 & 5.6 & 4.6 \\
2012 & 42.9 & 14.5 & 3.0 & 5.4 & 4.4 \\
2015 & 42.2 & 15.4 & 3.3 & 5.6 & 4.5 \\
2016 & 42.3 & 15.4 & 3.6 & & 4.3 \\
\hline
\end{tabular}

Source: author's own calculations based on: (UNCTAD, 2017).

Table 10. Shares of world GDP (PPP), export, FDI and labour productivity (USA=100) in 2000 and 2015/2016

\begin{tabular}{|c|c|c|c|c|c|}
\hline Country & European Union (28) & United States & Japan & Germany & China \\
\hline \multicolumn{6}{|c|}{ GDP (\%) } \\
\hline 2000 & 23.6 & 20.6 & 6.8 & 4.9 & 7.4 \\
\hline 2016 & 16.7 & 15.5 & 4.4 & 3.3 & 17.8 \\
\hline \multicolumn{6}{|c|}{ Export of goods and services (\%) } \\
\hline 2000 & 38.4 & 13.5 & 6.7 & 7.9 & 3.5 \\
\hline 2016 & 35 & 10.7 & 3.9 & 7.7 & 10.6 \\
\hline \multicolumn{6}{|c|}{ FDI (outflow, stock \%) } \\
\hline 2000 & 39 & 36.1 & 3.7 & 6.5 & 0.4 \\
\hline 2016 & 34.8 & 24.4 & 5.4 & 5.2 & 4.9 \\
\hline \multicolumn{6}{|c|}{ Labour productivity $(\mathrm{USA}=100)$} \\
\hline 2000 & 74 & 100 & 69.8 & 94.9 & 6.9 \\
\hline 2015 & 77.2 & 100 & 66.6 & 97.4 & 21.4 \\
\hline
\end{tabular}

Source: author's own calculations based on: (International Monetary Fund, 2017; OECD, 2017). 
A summary of the European Union's input into the development of the global economy was presented in Table 10. Data reveal that the EU's share in global GDP, exports of goods and services and foreign direct investment has declined, but the same can be said about all other analyzed economies with the exception of China. The economic leap of China and other emerging economies contributed to intensified de-concentration of economic activity and development, which, in turn, leads to the decline of highly developed countries' share in the world economy. Thus, analysis of this phenomenon within the largest economies of the world does not point to a particular decline of the EU's position in the world economy. The economic growth in Japan has been weakening since the mid1990s. China began to take over Japan's place as the center of Asia and the global economy. To evaluate the economic position of a country or group of countries, quantitative measures are used in addition to qualitative ones. The most important of these measures is labour productivity. Labour productivity indicators (Table 10) show a large gap of the EU in relation to the U.S. and an even greater gap between Japan and the United States. In the case of China, labour productivity is only slightly higher than $1 / 5$ of the U.S.

\section{Conclusions}

The hypothesis formed in the title calls for a clear assessment of the European Union's position in the global economy and within the system of economic powers. Taking into account quantitative measures such as share in global product, world exports of goods and services and world foreign direct investment stock, the highest decline of the EU's share occurred in the case of input to global GDP - by $6.9 \%$. However, this was similar to the U.S. share decline. The EU's share in world merchandise trade was lower by $4.3 \%$ in comparison with the year 2000, but in reference to the U.S. and Japan those results (including trade dynamics) can still be considered good, and share in global services exports is stable. The EU remains the top exporter of capital in terms of foreign direct investment.

Pertaining to the qualitative criteria the United States ranks better (in terms of labour productivity and total factor productivity TFP). Comparison of economic results of the EU with the U.S. revealed the advantage of the latter in terms of GDP growth rates, labour productivity, TFP and investment growth rates. Weakening of the European Union's position in the system of economic powers has progressed since the mid-1990s and was exacerbated due to the 2008-2009 crisis and post-crisis economic slowdown. Since 2014, the EU's GDP growth rate has been higher than the long-term trend (2000-2022) while in the U.S. it is variable and the forecasts point in favor of the EU (Figure 3).

The following factors contributed the most to the weakening of the global economic position of the EU and in particular in the system of economic powers: 1) ICT revolution in the U.S. and development of modern business and financial services contributing to the increase in U.S. labour productivity, 2) investment in the ICT sector in the EU were lower and did not become a driving force of economic development, 3) both demand and supply factors contributed to the widening of the EU's economic gap towards the U.S. in 20082016 and analysis of those factors revealed the variability of EU members in terms of ability for economic growth, 4) one of the barriers to growth in the EU in 2008-2016 was an increase in socio-economic divergence of its members and a crisis in the eurozone. 


\section{References}

Ark van, B., Chen, V., Colijn, B., Jaeger, K., Overmeer, W., Timmer, M. (2013). Recent Changes in Europe's Competitive Landscape and Medium-Term Perspectives: How the Sources of Demand and Supply Are Shaping Up. Economic Program Working Paper Series, EPWP \#13 - 05 (version 28 March 2013), The Conference Board.

Ark van, B., O'Mahony, M., Timmer, M. P. (2008). The Productivity Gap between Europe and the United States: Trends and Causes. Journal of Economic Perspectives, 22(1), 25-44.

European Commission. (2017). Quarterly Report on the Euro Area, Vol. 16, No 2, p. 31.

European Investment Bank. (2011). Productivity and growth in Europe: Long-term trends, current challenges and the role of economic dynamism, EIB Papers 16(1).

Eurostat. (2017). Eurostat database. Downloaded 10 October 2017 from: http://ec.europa.eu/eurostat/data/database.

Farhadi, M., Ismail, R., Fooladi, M. (2012). Information and Communication Technology Use and Economic Growth, Plos One, 7(1) e48903.

Frieden, J.A. (2006). Global Capitalism: Its Rise and Fall in the Twentieth Century. New York, W.W. Norton\&Company.

Hansen, J.D. (2003). Ekonomiczne aspekty integracji europejskiej (European Integration), Oficyna Ekonomiczna Kraków.

International Monetary Fund. (2017). World Economic Outlook Database, April. Downloaded 16 September 2017 from: http://www.imf.org/external/pubs/ft/weo/2017/01/weodata/index.aspx.

Keohane, R.O. (1984). After Hegemony: Cooperation and Discord in the Global Economy. Princeton: Princeton University Press.

Kohl, H. (2015). Convergence and divergence - 10 years since EU enlargement. Journal of European Social Policy, 21(3), 285-311.

Maddison, A. (1982), Phases of Capitalist Development, Oxford University Press.

Mucha-Leszko, B. (2014). Globalna czy regionalna liberalizacja handlu międzynarodowego. Współczesne Problemy Ekonomiczne (International trade liberalization - global or regional?). ZN Uniwersytetu Szczecińskiego. Współczesne Problemy Ekonomiczne. Globalizacja. Liberalizacja. Etyka, 8, 143-154.

Mucha-Leszko, B. (2014). Znaczenie i perspektywy euro w funkcji waluty rezerwowej (The role and perspectives of the euro as a reserve currency). Annales UMCS, Sectio H, Oeconomia, vol. 48(1), 151-160.

Oatley, T. (2008). International Political Economy. Interest and Institutions in the Global Economy. Pearson Longman.

OECD. (2017). OECD. Stat. Downloaded 16 September 2017 from: http://stats.oecd.org/.

O'Mahony, M., Ark van, B. (ed.). (2003). EU Productivity and Competitiveness: An Industry perspective. Can Europe Resume the Catching-up Process? European Communities.

Palan, R. (ed.). (2000). Global Political Economy: Contemporary Theories. London Routledge.

The Conference Board (2017a), Total Economy Database ${ }^{\mathrm{TM}}$ - Output, Labor and Labor Productivity, 1950-2016. Downloaded 16 September 2017 from: https:/www.conference-board.org/data/economydatabase/ index.cfm? id=27762.

The Conference Board (2017b), Total Economy Database ${ }^{\mathrm{TM}}$ - Regional Aggregates, 1990-2016. Downloaded 16 September 2017 from: https://www.conference-board.org/data/economydatabase/index.cfm?id=27762.

The Conference Board. (2017c). Total Economy Database ${ }^{\mathrm{TM}}$. Growth Accounting and Total Factor Productivity, 1990-2016 (Adjusted version), May. Downloaded 16 September 2017 from: https://www.conferenceboard.org/data/economydatabase/index.cfm?id=27762.

Twarowska, K. (2017). Ocena pozycji walut kluczowych międzynarodowego systemu walutowego w latach 1990 2016 i perspektywy (Assessment of the key currencies in international monetary system in 1990-2016 and the perspective of changes). ZN SGGW Problemy Rolnictwa Światowego, 17(2), 267-286.

UNCTAD. (2017). UNCTADStat. Downloaded 16 September 2017 from: http://unctadstat.unctad.org/wds/ ReportFolders/reportFolders.aspx?IF_ActivePath=P,15912\&sCS_ChosenLang=en.

World Bank. (2017). World Development Indicators database. Downloaded 16 September 2017 from: https://data.worldbank.org/data-catalog/world-development-indicators.

For citation:

Mucha-Leszko B. (2018). Causes of the European Union's Decreasing Position in the Global Economy in 2000-2016. Problems of World Agriculture, 18(1), 159-175; DOI: 10.22630/PRS.2018.18.1.15 